\title{
INSTITUTIONAL CHANGE IN INDUSTRIAL RELATIONS. STRIKE ARBITRATION IN SPAIN, 1880-1915*
}

\author{
JORDI DOMENECH \\ University of York ${ }^{\mathrm{a}}$
}

\section{RESUMEN}

Este artículo analiza los intentos por parte del estado español de ofrecer un marco regulatorio para las relaciones industriales a principios del siglo Xx. Se discute aquí que el conflicto principal se centraba en el reconocimiento de los sindicatos por parte de los propietarios de empresas, lo que hacía que cualquier acuerdo para finalizar huelgas en curso fuera muy inestable. Respondiendo a un movimiento obrero cada vez más activo, el Estado intentó regular las huelgas, pero sin embargo no se decidió a forzar a los empresarios a reconocer a los sindicatos. Esto dio pie a la formulación de un sistema transitorio que duró casi veinte años en el que el empresariado pedía constantemente al estado que garantizara la libertad de trabajo en las huelgas y el estado selectivamente desoía a los empresarios para forzarles a conceder algunas de las demandas de los trabajadores y evitar que los conflictos sociales adquirieran mayores proporciones. Se analiza con detalle el papel del estado en las huelgas y se muestra cómo la intervención de las autoridades - generalmente del gobernador civil- aseguraba la concesión de al menos algunas de

* An earlier version of this paper was presented at the Economics and Business History Seminar of Pompeu Fabra University, Barcelona in November 2003. I thank seminar participants for suggesting ways of improving this paper.

a Department of Economics and Related Studies, University of York, York YO10 5 DD, jd551@york.ac.uk. 
las reclamaciones de los trabajadores. Finalmente, se argumenta que este equilibrio institucional generaba la radicalización y movilización de empresarios y trabajadores.

Palabras clave: relaciones industriales, huelgas, cambio institucional, Restauración, España

\begin{abstract}
This paper analyses the attempts of the Spanish state to regulate industrial relations in the early $20^{\text {th }}$ century. The main conflict being over union recognition, workers faced strong opposition from employers, which generated a situation in which all possible agreements to end strikes were unstable. Faced with an increasingly active labour movement, the state tried to regulate industrial conflict but hesitated to apply state authority to force recalcitrant employers to recognize unions. A transitory system was in place for more than 20 years in which the state and employers clashed over the issue of the freedom to work and the state selectively applied its coercive power to force employers to give up on some of the strikers' demands. Tracing the role of authorities in strikes, I show how the intervention of state officials in strikes granted workers at least the partial satisfaction of their demands. I finally argue that state intervention in industrial conflict fuelled the radicalism of both unions and employers' associations.
\end{abstract}

Keywords: industrial relations, strikes, institutional change, Restauración, Spain

JEL Classification: J52, J58, J83, J88, K31

\title{
1. THE PROBLEM OF UNIONS
}

The evolution and consolidation of the Spanish labour movement has been one of the classical themes in Spanish contemporary history. Drifting towards radical politics and revolution, working class institutions have been traditionally singled out as one of the sources of instability within the pseudo-democratic regime of the Restauracion and the democratic experiments of the First and Second Republics. As Edward Malefakis put it, also in reference to the Italian case:

«[...] the Spanish and Italian working classes and their movements remained far less integrated with the rest of society than was true 
in Western and Central Europe, particularly in the pre-communist era. [...] There was no decrease in collective violence as worker organization spread, no reasonably secure hegemony of reformist leaders, [...], no abandonment of revolutionary goals in revolutionary situations for the defense of democratic capitalist regimes ${ }^{1}$.

In this paper, I concentrate on the reaction of the state to the spread of strikes in the early $20^{\text {th }}$ century to understand the origins of the corporatist formalization of industrial relations that took place in the mid 1920s and was consolidated during the Second Republic. In this context, corporatist institutions can be seen as an attempt to tame the potential revolutionary fervour of the Spanish working classes, a necessary condition for political stability, and, exclusively in the case of the Second Republic, also as an attempt by the state to incorporate the legitimate aspirations of the working classes into the polity of the country. As I show in the paper, however, the initial response of the state to strikes in the "formative» period of 1900-1915 was characteristically non-corporatist, relying on local authorities and a combination of conciliation and repression strategies.

In spite of the accumulated experience of social conflict in some of the main Spanish cities during the $19^{\text {th }}$ century, the levels of social unrest and the visible evolution of labour organizations shocked contemporaries in the late $19^{\text {th }}$ and early $20^{\text {th }}$ century. Probably no political or social issue generated more controversy than the so-called cuestion social (the social issue). After the general strike of Barcelona in 1902, a Conservative Catalan deputy claimed in Parliament: "I have known Barcelona for many years now, I have observed her in the most tragic moments, in political revolts, in mutinies [...], but I can say that I had never witnessed the spectacle of these last days ${ }^{2}$. In his view, the general strike had been an attempt to "stage what had been staged [sic] years ago in the Commune of Paris». According to one of the leaders of the Conservative Party, what had happened in Barcelona was «more serious than mutiny, more serious than sedition, more serious than revolution» ${ }^{3}$. La Veu de Catalunya, a conservative Catalan newspaper, woke up the spectres of Jacobin terror: "we seriously warn workers: our middle class is not as tame as the one that got herself killed in $1793{ }^{4}$.

Somewhat exaggerated, these impressions appeared in the wake of the labour movement after the period of relative social peace in the

\footnotetext{
Malefakis (1993), 59.

2 Diario de Sesiones del Congreso de los Diputados (henceforth, DSC) 1902, 3597.

3 DSC (1902): 3926.

4 Quoted in DSC (1902), 4015.
} 
second half of the 1880 s and 1890 s. The early 1880 s had witnessed a reorganization of the Spanish International and the resurgence of strikes in the period 1881-1883, but the events of the Mano Negra in 1883 were used to justify the repression of the rising strike movement and the banning of the International. In the 1890s, after the promising start of the celebration of the first May Day in Barcelona and Bilbao, the harassment of the state towards the anarchists, after their terrorist campaign in the mid 1890s, hindered the development of the labour movement. From 1899 onwards, an important cycle of strikes unfolded coupled with the re-organization of unions across Spain. In Barcelona, at the peak of strike wave in 1903-1904, about 60 per cent of the unions had been re-organized or created from scratch in the years 1899-1904 ${ }^{5}$. In the important Catalan textile industry, a federation of unions (Federación de la Industria Textil Española) was created in $1899^{6}$. The construction workers of Barcelona won a 13,000 strong strike in Barcelona in which the eighthour day was conceded. In the area of Bilbao, after the successful May Day strike of 1890, no other general strike was organized until 1903. Among miners in Asturias, an ultimately failed unionization drive was attempted in 1903. More importantly, a recently created Federación de Sociedades Obreras de la Región Española (Spanish Federation of Spanish Workers' Resistance Societies) organized a series of general strikes in the years 1901 and 1902 in some important provincial capitals -like Barcelona, Oviedo, Gijón, Valencia, La Coruña, or Zaragoza-, and in several Andalusian towns ${ }^{7}$.

Even if demands to shorten the workday or to raise wages were central to the unions' program, the aspirations of organized labour did not focus exclusively on economic demands. The strike wave of 1899-1903 attempted to re-shape the employer-workers relationship by requiring employers to accept a written collective contract (bases de trabajo) or to concede a symbolic demand such as the eight-hour day. Therefore, the final objective of the strike movement was the more fundamental demand of union recognition, i.e. the right of unions to participate in the collective determination of working conditions and the recognition by employers of the bargaining power of organized labour.

In this paper, I consider the Spanish debate on the role of unions and the dynamics of institutional change on the creation of formal bargaining institutions. I argue that the private solution to this social problem was impossible given distributional conflicts and transaction costs

${ }^{5}$ IRS (1907). For the case of Valencia in which re-organization also took place after 1899: Reig (1986): 259-61.

6 Bengoechea (1994), 129

7 On the whole episode, Díaz del Moral (1973), 171-172. 
making private, voluntary agreements difficult and unstable. When this is so, the literature on institutional change argues that, in the case of a failure of the private solution, agents with an interest in reform might see the political solution as the most cost-effective means of overcoming the transaction costs that hinder the private solution ${ }^{8}$. Following this logic, workers turned to the public arena to express their grievances. Strikes, especially large strikes in important cities, necessarily involved political and military authorities in the solution of the conflict. In the period, an «informal» system of strike arbitration (e.g. not institutionalized by the force of law) was created in which strikers, employers, and state officials interacted strategically ${ }^{9}$. Strike waves and unionization drives did not require a top-down political change, as described in Olson's explanation of union growth in which the state's support of collective bargaining through laws on strike arbitration and collective bargaining is the crucial factor explaining workers' mobilization ${ }^{10}$. Along with Edward Shorter, Charles Tilly and Gerald Friedman, all writing with specific reference to the French case, I stress that the strategic interaction between state and the labour movement, rather than deciding state support of the labour movement, explains processes of union growth and strike waves in the late $19^{\text {th }}$ and early $20^{\text {th }}$ centuries, as well as the characteristics of collective mobilization of both workers and employers ${ }^{11}$. Topdown and bottom-up forces, to use the terms coined by Richard Freeman in his influential paper on processes of union growth, seem to have been equally important ${ }^{12}$. Spanish labour history has probably put excessive emphasis on bottom-up processes of labour mobilization, which only consider exogenous social, organizational, and economic changes within the labour movement. Gerald Brenan identified the spread of anarcho-syndicalism in Catalonia with the immigration of mostly illiterate peasants from Andalusia, echoing the early association made by Juan Díaz del Moral of the revolutionary hopes of the Andalusian peasantry with forms of popular religiousness ${ }^{13}$. In his authoritative work on Catalan unions from 1903 to 1920, Pere Gabriel stresses the organizational innovation of the sindicato único, or «one big union» in the translation of Benjamin Martin, in explaining the rise of the National

\footnotetext{
${ }^{8}$ North (1987), Libecap (1989).

9 Describing these institutions as «informal» is in itself problematic. In the institutional literature, the term «informal institutions» refers to institutions that do not have an external enforcer. In my argument, the state acts as «external enforcer» but does not follow a set of predefined operational rules. Knight (1992), 172-3.

10 Olson (1995), 79.

11 Shorter and Tilly (1974), 39. Friedman (1998), 13.

12 Freeman (1997), 9-10.

13 Brenan (1943), 185. Díaz del Moral (1973 [1928]), chapter 1. See also Meaker (1974), 2.
} 
Confederation of Labour (CNT) since $1916^{14}$. Other authors have focused on structural problems in the economy. Joan Connelly Ulman considered widespread unemployment among Catalan textile workers in the early $20^{\text {th }}$ century as one the main explanations of the first general strike in Barcelona in 1902 and of the popularity of anarcho-syndicalism in Catalonia ${ }^{15}$. More recently, Angel Smith focused on the erosion of working conditions in several trades in Barcelona to explain most of the radicalization of the labour movement in the city after $1907^{16}$.

These explanations, although attractive, have several problems. First, the literature on collective action generally stresses that there is a weak link between poverty and collective action ${ }^{17}$. Alienated, recent immigrants were not at the forefront of urban labour struggles in the late 1910s, especially because Andalusian peasants constituted only a tiny portion of the immigrants to Catalonia and the North of Spain in the early $20^{\text {th }}$ century. Second, it is not clear that the sindicato unico was the optimal institution. This organization orchestrated an extraordinarily successful general strike in Barcelona in 1919, but could not maintain the spectacular membership gains of 1918-1919. Rather, the único was an adequate institution given the political context of the years 1918-1920 and membership simply responded to changes in the costs of collective action caused by changes in government policy towards unions. Finally, structural explanations based on changes in the economy do not fit the timing of strike waves in early $20^{\text {th }}$ century Spain. They might well explain the strike wave of 1902-1903 as a response to some previous or contemporary economic crisis, but fail to predict the increases in strike activity in other years, especially in the early 1910s. In contrast with previous explanations, the aim of this paper is to put state policy and its crucial interaction with unions in the history of the Spanish labour movement during the Restauración. The main reason for doing this is to achieve a more adequate balance between top-down and bottom-up explanations of the evolution of the labour movement in Spain.

\section{DISTRIBUTIONAL CONFLICTS}

Distributional conflicts were a serious limitation to the recognition of unions and the organization of formal institutions for collective bargaining like arbitration committees and joint boards of independent wor-

\footnotetext{
14 Gabriel (1981), 706-728; Martin (1990), 198

15 Ulman (1968), 68.

16 Smith (1991).

17 Richards (2002), 4.
} 
kers' representatives and employers. When tried, these organizations proved to be extremely unstable and they rarely operated for more than some months after a strike had taken place. The literature on institutional change argues that when the number of potential bargaining agents is large and agents have private information, the co-operative solution to the collective problem breaks down ${ }^{18}$. If there is asymmetric information and the number of bargaining agents is large, every agent has an incentive to misrepresent the true expected pay-offs from the new institution - potential losers would over-report expected losses- leading to inefficient outcomes, e.g. a potentially more efficient institution would not be adopted. In the period, however, the greatest resistance to the recognition of unions was found in the highly concentrated mining, railways or iron and steel sectors, where the number of bargaining agents was small in relative terms. Moreover, in spite of the fact that employers' associations in the early $20^{\text {th }}$ century were poorly developed, unions minimized the number of bargaining opponents by selecting the largest employers in a given town ${ }^{19}$. For example, the textile workers' strike in Manresa, leading to a general strike in the whole sector in the summer of 1890, was organized against a pay cut in the factory Els Dolors, or, in 1906, the failed unionization drives of the Asturian miners' union centred around Hullera Española ${ }^{20}$.

A more plausible explanation is that compensating payments for employers could not be devised and that, because agreements were not binding, the organization of a collective bargaining system required restraint on the part of workers and reducing post-strike employers' opportunism ${ }^{21}$. Transactions costs and distributional conflicts therefore prevented efficiency-enhancing institutional change. For example, with a royal decree establishing mandatory hours ceilings after the textile strike of 1913, employers conditioned their acceptance of the 60 hour working week on the reduction of the "surcharges of 10 and 15 per cent on industrial taxes in water-powered factories and a general reduction in industrial tax rates", accompanied by the pressure of the government on railway firms to reduce transport fares for raw materials and manufactured goods ${ }^{22}$. In addition, employers demanded that any agreement

\footnotetext{
18 Mailath (1990).

19 Bengoechea (1994), 126-144.

20 Ferrer (1974), 65; Martin (1990), 197.

21 Examples of cases in which employers did not respect the agreements in the strikes of 1903 in Sastre (1904), entries for "fundidores de bronce y otros metales», "picapedreros", "empleados de la compañía de tranvías».

22 Sastre (1914), Memorándum de la Comisión de Fabricantes de Hilados y Tejidos del Llano y la Montaña, 219, and Informe de la Cámara Oficial de Barcelona elevado al presidente del Instituto de Reformas Sociales, 223-4.
} 
taken to settle the strike be binding for ten years ${ }^{23}$. Since there is no evidence that these demands were ever met, the decree failed to be enforced and caused multiple conflicts up to 1918. Other cases of political horse- trading can also be found in the large mining strikes of 1903 and 1910 or in the railway workers' strike of 1912 .

Given these difficulties, except for some extremely stable sectors like barrel-making, the printing trades or hat making, characterized by small establishments employing highly skilled workers, voluntary agreements between employers and workers to sustain collective bargaining institutions were extremely unstable and only supported by exceptional economic circumstances. After a series of failed union recognition strikes, employers finally recognized the Asturian Miners' Union in 1912, a period of fast growth of exports ${ }^{24}$. Catalan textile workers only enjoyed more or less sustained collective bargaining in the early 1880s, and that only in the large establishments around Barcelona ${ }^{25}$. The joint board of employers and workers devised as a solution to the 1890 strike in Manresa was short-lived and the subsequent employers' lock-out marked the decline of the Tres Classes de Vapor in the Catalan textile sector ${ }^{26}$. In Barcelona, building construction workers were formally engaged in a period of collective bargaining with their employers after the 1901 strike, which included the creation of a joint board of workers and employers, which however rarely met and could not avoid another strike in $1903^{27}$. After the strike failed and with the end of exceptional labour market conditions, employers turned to individual contracting. Exceptional labour market conditions in the Madrid building industry made collective bargaining possible up to $1911^{28}$. These examples contrast with the case of the metal workers of Barcelona, who were never able to enforce a collective contract with employers in spite of spectacular general strikes in late 1901 and in 1910.

\section{STATE POLICY}

At the same time that unions pushed for recognition and their subsequent stabilization in a system of collective bargaining, a set of jurists and political writers, following developments from more advanced nations like Germany, France or Italy, recognized the deficiencies of the

\footnotetext{
23 Ibid., 219

24 Shubert (1984), chapter 5.

25 Izard (1973), 77-88.

26 Ferrer (1974), 66, on the Comisión Mixta; on the lock-out, Izard (1973), 100-101.

27 Sastre (1904), Obreros de la construcción.

28 Byrne (1992).
} 
classic liberal codes inherited from the Napoleonic code and the need to make parts of the existing codes more «social», i.e. adapted to the rise of labour unrest and other related problems like poverty or urban squalor. In the views of the leading members of this group of reformers, the principle of free contract was to be overcome by the recognition of the inherent weakness of workers in the contract relationship and the need to involve workers in the collective negotiation of working conditions to curb labour unrest.

Despite their alleged sympathy for working class organizations, reformers were keenly aware of the political and potentially revolutionary content of Spanish unions. According to the social-catholic sociologist Eduardo Sanz Escartín, the Spanish working class was dominated by «anti-social anarchism» ${ }^{29}$. Another contemporary observer noted that

«the revolutionary agitation is not receding, all the contrary, it is gaining strength, predominating in our country, among the working classes, the influence of anarchism, which has caused the violence and the social indiscipline characterising the most recent strikes having been staged in Spain» ${ }^{30}$.

Yet reformers believed that the political and revolutionary expression of unions was simply temporary and stressed that unions were «not only resistance societies [sociedades de resistencia]» but also legitimate participants of the polity supplying socially useful institutions to their members. Reformers noted that if one took the time «to take a look at the rules governing many workers' unions», it was easy to appreciate the usefulness of «the articles containing the supply of vocational training, the election of vocational committees, unemployment agencies, mutual benefit and old age funds». They maintained that the main aim of unions was not political, but «the elevation of wages, the shortening of the workday, and the improvement of working conditions» ${ }^{31}$. Even in more conservative quarters, it was accepted that «the activities of unions not only bring about material results but also contribute powerfully to create the habits of order and morality» ${ }^{32}$.

Using an international comparison, reformers opposed to radical Italian or Spanish unions, the example of the moderate British, American or German unions, a line of reasoning they adopted from French and Italian reformers. In Britain or Germany, unions «so power-

\footnotetext{
${ }^{29}$ Gascón y Marín (1907), volume I, 132

30 Fernández Jiménez (1904), 12.

31 Gascón Marín (1907), volume I, 120

32 Sanz Escartín (1896), 243.
} 
ful that employers do not dare to refuse to negotiate with» had brought about social peace and a decline in strike activity. Where unions were weak, like in Italy, Spain or Russia, political radicalism, strikes and revolutionary hopes were the norm ${ }^{33}$. Considering that «the bitterness of strikes is inversely related to the progress, the strength, and the discipline of unions» ${ }^{34}$, the stabilization of unions inevitably led to bread-and-butter unionism, the respect for property rights, and the abandonment of political radicalism. In this view, the control of strike-funds by a central bureaucracy and the supply of institutions like friendly societies and unemployment insurance tamed workers' revolutionary hopes and committed them to a more gradualist agenda focused on economic objectives. Employers, the famous Republican academic Gumersindo de Azcárate remarked, should not fight unions but rather «wish all their workers joined the union», because a union «allows to substitute reflection for what previously was only impulse» ${ }^{35}$. Reformers admired the «self-control,» the "virility» and the «instruction» of the British trade unionist, as opposed to the Spanish worker, considered to be too ignorant and hot-headed ${ }^{36}$.

Following this line of reasoning, the role of the state was to sponsor freely constituted unions of workers and collective bargaining as a means to curb labour unrest. In an early formulation, the sociologist Sanz Escartín asserted that «the future civilization, [...], must rest on freely constituted associations [...] able to harmonize all social interests through a higher co-ordinating body» ${ }^{37}$. Later on, reformers moved away from harmonic views of society in which all conflicting interests would be reconciled and ended up recognizing the necessary role of state coercion and enforcement. Gumersindo de Azcárate argued that «the moral duties of property are nowadays trusted to private initiative, [but] there is no guarantee of their indispensable compliance, [therefore] it is absolutely necessary to pass laws to make sure they are effective» ${ }^{38}$. Following this argument, the liberal Minister of Agriculture, Trade and Industry, José Canalejas, affirmed in 1902 that «where the state does not intervene to regulate or soften the battle of the classes, where govern-

33 Buylla, Posada, Morote (1986 [1902]), XVII. Same argument in Gascón Marín (1907), volume I, 26; Fernández Jiménez (1904), 131; Zancada (1902), 225; Sanz Escartín (1896), 243; Buylla and González Alegre (1910), 105; Roig i Bergadà, DSC 1902, 3949; Eduardo Dato, DSC 1902, 3809-3810, quoting Fernández Villaverde's speech delivered at the Academy of Jurisprudence in 1901.

34 Buylla et al. (1986 [1902]), CXL.

35 DSC 1910, 1227.

36 Sanz Escartín (1896), 28.

37 Ibid., 237.

38 De Azcárate quoted in Fernández Jiménez (1904), 111. For a slightly more conservative view see Azcárate (1904). 
ments are reluctant to address the social problem, everything is burned down by the anarchist fire» ${ }^{39}$. He went on to argue that «the fact that employers do not respect the law [mainly thinking about the non-recognition of legal unions] is what drives thinkers ["hombres pensadores"] towards the option of compulsory arbitration and the coercion of the state». And finally concluded: «we require the worker to respect the law and keep away from the streets [...] to make life in freedom viable, making social progress possible, but let's ask employers as well to respect legal precepts» ${ }^{40}$.

Instead of complying with employers' demands to simply guarantee the freedom to work, reformers believed that the end of the social question would be brought about by the decided state sponsorship of arbitration and conciliation procedures resting on powerful independent unions. In the opinion of reformers, «the most effective [state] intervention is to sponsor large unions, with strong funds making them powerful and conservative at the same time; the joint boards, elected by the unions and employers' associations, will follow to protect the common good ${ }^{41}$. Considering the task of joint boards in Belgium, a Catalan republican deputy who favoured the compulsory arbitration of strikes claimed that

«those boards include workers and employers, [...] creating among them the habit of friendship, fraternity, and affection, which in the future will probably become a buffer against solvent theories and against the dreadful ideas that the anarchists try to instil in our working classes» ${ }^{42}$.

Minister Canalejas summarized the optimistic view of reformers on conciliation institutions when stating that "when workers' associations finally reach their full potential, there will be no more strikes» ${ }^{43}$.

In spite of the existence of similar views among academic circles and in some political groups, almost thirty years separate the early formulations addressing the social question from the reforms required to the passing of a bill on strikes and joint commissions in 1908 and 1909. Three factors seem to explain this delay. First, the coalition of reformers was still small and politically isolated. Republicans represented less than ten per cent of the Chamber. Among the Liberals, there was a large group

${ }^{39}$ Canalejas, DSC 1902, 53.

40 Ibid., 53.

41 Maura Gamazo (1901), 217.

42 Roig i Bergadà, DSC 1902, 3950.

43 Quoted in Fernández Jiménez (1904), 365. 
favouring a laissez-faire, abstencionista policy. Only those identified with social Catholicism and regeneracionismo within the Conservative party were decidedly committed to social legislation, albeit often not fully accepting the right of workers to organize unions, and to state regulation of class conflict. A second factor was political instability. Lacking political leadership after the deaths of Antonio Cánovas del Castillo and Práxedes Sagasta, Conservatives and Liberals were split into different factions leading to unstable, short-lived governments unable to pass crucial legislation. It was not until the «long» Conservative government of Antonio Maura, himself not identified with the reformist factions of the Conservatives, with a cohesive majority in Parliament, that the bills on strikes and conciliation boards could be passed. Finally, a third, contributing factor might have been the low levels of strike activity in the period 1905-1909 which might have reduced opposition to any law regulating industrial relations.

The strike laws passed by the Maura government established the institutions which could have led to the formal legal recognition of unions' bargaining rights and a move towards an incipient corporatist organization of industrial relations in Spain at the local or regional level. Industrial tribunals had jurisdiction over labour contracts and were designed to settle minor disputes avoiding costly strikes or the slower ordinary tribunals. The law on conciliation boards allowed the local boards of social reforms (juntas de reformas sociales, created by the 1900 accidents law) to arrange the settlement of strikes, if the contending parties accepted to do so. The laws officially recognized unions by stipulating their participation in mixed institutions with representatives of employers and political authorities, while at the same time put a limit on the ability of workers and employers to coerce each other.

The historical literature has considered these laws to be quite conservative, given the limitations on the workers' right to strike. However, this judgement does not take into account the political opposition to the law and lacks comparative perspective: Belgium, Italy or France had more restrictive laws, for instance establishing more severe penalties for picket lines ${ }^{44}$. Contemporary critics of conciliation procedures remarked only some years later that «shortly after being passed, the law was implemented in the social reality [sic] ...in its most extreme and radical sense». Referring to the general strikes of 1911 and 1916, it concluded: «this law is the cause of the terrifying general strikes we have witnessed lately» ${ }^{45}$.

44 Comparisons given in DSC 1909, 3167-3174.

45 Financiero Hispano-Americano (1916), 22. 


\section{THE CONFLICT OVER THE FREEDOM TO WORK}

It is clear, however, that the 1909 reforms failed to be implemented. According to the strike data published by the Instituto de Reformas Sociales (IRS) from 1905 to 1920, a local junta intervened in only 3 per cent of the strikes in 1905-1909, while it only did so in 3.5 per cent of strikes in 1910-1915. Using the strike data collected by the Catalan Museu Social (Social Museum) for the period 1912-1915, local boards of employers and employees only intervened in 5 per cent of the 315 recorded strikes in the period ${ }^{46}$. Writing with historical perspective, the Ministro de Gobernación of the time, Juan De la Cierva, who, like Maura, did not have any reformist credentials, lamented that the laws on strikes and conciliation boards had not been enforced since he had left the ministry ${ }^{47}$. In 1909, the labour inspectors of the Catalan provinces found that "with the exception of very few towns, where industry is very important, in many towns local boards have been barely organized but have never met, in others they meet only rarely, their activities being generally fruitless» ${ }^{48}$. The labour inspectors in the Basque provinces remarked in 1911 that local boards were "purely nominal, inert bodies, ignorant of their duties» ${ }^{49}$.

The first problem was that participation in the arbitration boards was voluntary. Labour inspectors mostly blamed employers for hindering the institutionalization of conciliation boards. The labour inspectors of the Catalan provinces claimed that «employers only intervene in them [the boards] to avoid the harm that workers can cause to them». But the inspectors went on to say that it was always «the members elected by the workers who drive the boards to reach agreements» ${ }^{50}$. Similarly, other inspectors echoed the protest of employers about the activities of the local boards, which employers grounded in the fact that the «board members from the working class cannot put aside their hate for the employers' class or lack the necessary technical expertise ${ }^{51}$. Labour inspectors in the Andalusian provinces lamented that «employers are not willing to accept any demand put forward by the workers, because they believe it is a humiliation» ${ }^{52}$.

The second and more important factor is that an informal system of strike resolution was already implemented in the first decades of the $20^{\text {th }}$

\footnotetext{
${ }^{46}$ Catalan strikes represented an important share of Spanish strikes: between 1910 and 191531 per cent of strikes happened in Catalonia, representing 50 per cent of strikers and 62 per cent of man-days lost in Spain in 1910-1915.

47 De la Cierva (1955), 120.

48 IRSc, year 1909, 60

49 IRSc, year 1911, 106. Other examples in 1911, 68-69, 70, 72, 142, 184, 218, 258.

50 IRSc, year 1909, 60.

51 Ibid., 86.

52 IRSc, year 1910, 120.
} 
century. Relying on the will of capitalists, formal corporatist institutions could not substitute for a well-established system of strike arbitration dependent on the intervention of state officials. Prefects, the highest state authority at the level of the province, and occasionally mayors, had a fundamental role in the settling of disputes ${ }^{53}$. In the period 1905-1909, some external authority intervened in about 30 per cent of strikes, with almost two thirds of these interventions being made by prefects ${ }^{54}$. In the early 1910s, the proportion increased to 35 per cent of strikes, representing about 60 per cent of strikers. To give some comparative dimension to these numbers, in France in the period 1910-1914 with a very similar delegation of state authority at the provincial or departmental level, the government intervened in about 15 per cent of all strikes ${ }^{55}$. In general, state mediation in strikes had a characteristic advantage over purely voluntary systems of conciliation: prefects could force recalcitrant employers into accepting some of the demands of strikers because employers needed state protection to defend their establishments from picket lines. As I show below, the conflict of interests between state officials and employers in Catalonia and Biscay had been apparent since the early $20^{\text {th }}$ century.

The published data on strikes allow us to measure the impact of prefects' and local authorities' mediation on the settlement of strikes and, in a second set of regressions, to identify the factors explaining the participation of state and local authorities in the conflict ${ }^{56}$. The purpose here is largely descriptive and is thought to provide a stimulus for further research using strike data from Spain and other Western European countries. One problem, impossible to solve at this stage, is the endogeneity of the state intervention in strikes with respect to strike characteristics, mainly because instruments explaining strike success or state intervention independently are not obvious. Moreover, following Card and Olson (1995), the appropriate estimation strategy is to estimate three duration models for different strike settlements - won strikes, lost strikes, and compromises. However, Card and Olson (1995) did not include state intervention in the strike in their war-of-attrition duration model and there is no clear prediction of the effect of state intervention on strike durations ${ }^{57}$. Strikers might be willing to hold out longer becau-

\footnotetext{
53 On the origins of the institution: Risques Corbella (1995).

54 Data are from IRSb, years 1905 to 1909.

55 Friedman (1988), 7.

56 The two main aggregate sources of strike data for the period are: IRSb (various years), covering the period 1905-1922, and Museu Social (1913-1916), which collect data on Catalan strikes from 1912 to 1915.

${ }^{57}$ In fact, they test their war-of-attrition model using 1880 s data from the US because of the existence of few compromises, probably because of limited state intervention in the strike. Card and Olson (1995), 43.
} 
se they know the state might eventually intervene or employers, because state intervention magnifies the strikers' threat and extends workers' capitulation times, might consider capitulating earlier ${ }^{58}$.

According to the strike data collected by the Instituto de Reformas Sociales (IRS) from 1905 to 1909 civil governors intervened in almost a fifth of strikes and mayors in 11 per cent of strikes ${ }^{59}$. In order to assess whether the participation of prefects favoured workers, a logistic regression was carried out in which the outcome of the strike depends on a set of strike characteristics, geographical factors and year dummies, plus a variable capturing the way in which the strike was settled (the control group being the cases when no authority intervened in the settlement of the strike). Focusing on the intervention of state officials from 1905 to 1909 , their intervention was associated with an increase in the probability of settling the strikes in favourable terms for the workers of 41 per cent in the case of both complete and partial victories and 96 per cent when only complete victories are considered (marginal effects calculated from logit regressions in table 1) ${ }^{60}$. Comparing the effect of state media-

${ }^{58}$ Card and Olson (1995), see also Huberman and Young $(1999,2002)$ for an extension of the model to include compromise settlements to the strike.

${ }^{59}$ What was understood by intervention of the civil governor is problematic. In the IRS strikes I used the entry «observaciones» which included comments like «intervino el señor Gobernador civil de la provincia» (the civil governor intervened) or "a propuesta del gobernador civil se avinieron las dos partes en conflicto" (workers and employers reached an agreement after the initiative of the civil governor). The quality of this entry is good for the period 1905-1909 when each strike included a comment. This might imply that the IRS only selected a sub-sample of strikes for which it had complete information. Comparison of the IRS data for Barcelona in 1905-1909 with those of other sources (Sastre (various years), however, suggests the differences between both sources were not drastic. In 1905, the IRS gave information on 25 strikes in the city of Barcelona, while Sastre collected 24. For 1906, the IRS gives 19 strikes and Sastre 24. In 1907, the IRS counted 15 strikes and Sastre 21. Figures for 1908 and 1909 are 19 and 22 and 12 and 12 respectively. We do not know, however, what happened in more remote areas or in smaller cities. Strike data lose quality after 1910 when the IRS did not add comments for each strike about the type of settlement and probably focused more explicitly on the formation of conciliation boards and mixed commissions after the passing of the 1909 law on strikes. A comparison of data from the IRS and Museu Social shows how this was the case. In the period 1912-1915 the IRS reports 271strikes in the Catalan provinces while the Museu gives 315. Of these, the IRS reported the governor intervened in only 4 per cent of the cases, while this proportion reaches almost 20 per cent according to the Museu Social. The evidence on conciliation boards was more accurate and consistent in both sources: the IRS reported that a local junta o comisión mixta settled the strike in 5 per cent of the cases (13 out of 271), as did the data of the Musu Social (16 out of 315). Again, this check cannot be extended with confidence to other areas.

60 Won strikes were coded as "ganada totalmente», compromises as "ganada parcialmente» and lost strikes as "perdida». Distinguishing between won and lost strikes and compromises can involve several empirical problems if strike outcomes - for instance wage increases or shorter hours - are distributed continuously. However, it was the natural taxonomy used to describe outcomes in the period, suggesting contemporaries identified clearly when a strike was won, lost or only partially won. The distinction between successful and failed 
tion on strike outcomes with the effect of other strike characteristics shows how the intervention of prefects was the main predictor of strike success ${ }^{61}$.

Carrying out the same exercise with a sample of Catalan strikes in 1912-1915, the intervention of prefects raised the probability of partial and complete victories by 44 per cent and of complete victories by 67 per cent (coefficients in table 2). Mayors also had a large impact on the probability of reaching a compromise, but not on the probability of winning the strike completely.

The fact that in both sets of strikes state intervention increased both the number of complete victories and compromises proves that prefects favoured workers, and, that if workers attracted the support of state officials, there were great chances of winning the dispute. These results admittedly do not include all the range of actions by prefects, which could entail arresting the main strike leaders, banning union meetings, and crushing picket lines. But the analysis of both the 1905-1909 strikes and the 1912-1915 strikes shows that: 1) a significant fraction of state interventions in strikes favoured workers, as much as repression might have favoured employers; 2) if workers could attract favourable state intervention, this intervention was effective.

A second issue centres on an understanding of the determinants of state intervention in strikes, i.e. when did prefects decide or receive orders to support workers? I use the same strike data but now I use state intervention as the dependent variable, which I consider depends on a set of strike characteristics, geographical factors, electoral factors and year dummies. Including electoral factors is largely exploratory here and used to assess the reaction of the state to a wider support for anti-system parties (Republicans and Socialists), which could be quite significant in some of the main cities (Republicans, for example, dominated local politics in Valencia and Barcelona). Anti-system political movements supported the grievances of the labour movement, amplified the publicity of strikes through the political press and provided the leadership in particular strikes ${ }^{62}$.

strikes and compromises was adopted by Miguel Sastre in his yearbook of strikes in Barcelona between 1903 and 1914, by the IRS and later the Ministry of Labour between 1905 and 1935 and by the Museu Social from 1912 and 1915. This taxonomy was also used in the French, Canadian or American data of the period. Sastre (various years), IRSb (various years), Museu Social (various years). On American and French strike data see Friedman (1988), 1-25. On Canada see Huberman and Young (1999).

${ }_{61}$ In France, in the period 1895-1914, government intervention in strikes increased the probability of partial or complete victory by 30 per cent.

62 Fusi (1975), 65-81; Cullà (1986), 87-91; Álvarez Junco (Madrid, 1990), 270-71; Ullman (1968), 71; Reig (1986), 253-69. 
TABLE 1

FACTORS AFFECTING THE PROBABILITY OF WINNING STRIKES, SPAIN 1905-1909

\begin{tabular}{|c|c|c|c|c|c|}
\hline \multirow[b]{2}{*}{ Variables } & \multirow[b]{2}{*}{ Means } & \multicolumn{2}{|c|}{$\begin{array}{c}\text { 1. Strike outcomes, } \\
\text { 1905-1909 } \\
\text { Victories and } \\
\text { compromises. Mean: } 0.5\end{array}$} & \multicolumn{2}{|c|}{$\begin{array}{l}\text { 2. Strike outcomes, } \\
\text { 1905-1909 } \\
\text { Victories only } \\
\text { Mean: } 0.34\end{array}$} \\
\hline & & Coeff & Mg eff & Coeff & Mg eff \\
\hline Constant & 1 & $\begin{array}{c}1.69 * * * \\
(0.65)\end{array}$ & & $\begin{array}{c}1.73 * * * \\
(0.71)\end{array}$ & \\
\hline Log (days on strike) & 2.29 & $\begin{array}{c}-0.4 * * * \\
(0.08)\end{array}$ & -25.84 & $\begin{array}{c}-0.46 * * * \\
(0.09)\end{array}$ & \\
\hline Log(strikers) & 3.81 & $\begin{array}{l}-0.07 \\
(0.08)\end{array}$ & $(0.09)$ & $-0.2 * * *$ & \\
\hline $\log ($ striker rate $)$ & -0.45 & $\begin{array}{c}0.48 * * * \\
(0.14)\end{array}$ & 17.69 & $\begin{array}{c}0.45 * * * \\
(0.15)\end{array}$ & \\
\hline City $10,000-25,000$ & 0.17 & $\begin{array}{c}0.22 \\
(0.31)\end{array}$ & & $\begin{array}{c}0.37 \\
(0.33)\end{array}$ & \\
\hline City $25,000-50,000$ & 0.09 & $\begin{array}{l}0.03 \\
(0.4)\end{array}$ & & $\begin{array}{c}-0.3 \\
(0.44)\end{array}$ & \\
\hline City $50,000-100,000$ & 0.08 & $\begin{array}{l}-0.14 \\
(0.42)\end{array}$ & & $\begin{array}{c}0.1 \\
(0.45)\end{array}$ & \\
\hline City over 100,000 & 0.4 & $\begin{array}{l}-0.41 \\
(0.31)\end{array}$ & & $\begin{array}{c}0.01 \\
(0.03)\end{array}$ & \\
\hline Civil governor $($ yes=1) & 0.17 & $\begin{array}{l}0.69 * * \\
(0.29)\end{array}$ & 40.71 & $\begin{array}{l}1.1^{* * *} \\
(0.31)\end{array}$ & 95.52 \\
\hline Mayor (yes=1) & 0.11 & $\begin{array}{l}0.56^{*} \\
(0.33)\end{array}$ & 32.6 & $\begin{array}{c}0.35 \\
(0.36)\end{array}$ & \\
\hline Junta Local (yes=1) & 0.03 & $\begin{array}{c}0.99 \\
(0.53)\end{array}$ & 57.38 & $\begin{array}{c}0.48 \\
(0.61)\end{array}$ & \\
\hline Type of strike issue (5) & & Yes & & Yes & \\
\hline Type of industry (15) & & Yes & & Yes & \\
\hline Year dummies (4) & & Yes & & Yes & \\
\hline Region dummies (3) & & Yes & & Yes & \\
\hline $\log \mathrm{L}$ & & -328.43 & & -294.3 & \\
\hline Chi-Squared & & 102.83 & & 113.54 & \\
\hline$\%$ correctly classified $* * * *$ & & 67.15 & & 74.82 & \\
\hline Number of observations & & 548 & & 548 & \\
\hline
\end{tabular}

Source: IRSb, years 1905-1909.

Notes: $* * * * * *$ indicate statistical significance at better than 1,5 and 10 per cent in two sided z-tests. Standard errors in parentheses. Marginal effects measure the percentage change on the estimated baseline probabilities caused by one standard deviation change in each particular variable's mean, holding all other variables at their sample means. The estimated marginal effects of the dummy variables are changes from 0 to 1 . Marginal effects in italics are significant at standard levels of significance.

Region dummies: Mediterranean, South, North, with control group being the two Castiles.

$* * * *$ cut-off probability $=0.5$. 
TABLE 2

FACTORS AFFECTING THE PROBABILITY OF WINNING STRIKES, CATALAN STRIKES 1912-1915

\begin{tabular}{|c|c|c|c|c|c|}
\hline \multirow[b]{2}{*}{ Variables } & \multirow[b]{2}{*}{ Means } & \multicolumn{2}{|c|}{$\begin{array}{c}\text { Model 1 } \\
\text { Victories and } \\
\text { compromises. Mean: } 0.57\end{array}$} & \multicolumn{2}{|c|}{$\begin{array}{c}\text { Model } 2 \\
\text { Victories only } \\
\text { Mean: } 0.36\end{array}$} \\
\hline & & Coeff & Mg effect & Coeff & Mg effect \\
\hline Constant & 1 & $\begin{array}{l}0.39 \\
(0.75)\end{array}$ & & $\begin{array}{c}0.49 \\
(0.77)\end{array}$ & \\
\hline Log (days on strike) & 2.2 & $\begin{array}{c}-0.26^{* *} \\
(0.1)\end{array}$ & -15.5 & $\begin{array}{c}-0.28 * * \\
(0.11)\end{array}$ & \\
\hline Log(strikers) & 4.15 & $\begin{array}{l}-0.01 \\
(0.09)\end{array}$ & $-0.16^{*}$ & $(0.1)$ & \\
\hline Log(striker rate) & -0.29 & $\begin{array}{l}0.45^{*} \\
(0.25)\end{array}$ & 11.03 & $\begin{array}{l}0.29 \\
(0.26)\end{array}$ & \\
\hline Union (Yes=1) & 0.81 & $\begin{array}{l}0.88^{* *} \\
(0.41)\end{array}$ & 53.46 & $\begin{array}{l}0.82 * * \\
(0.42)\end{array}$ & \\
\hline $\begin{array}{l}\text { Employers' association } \\
(\text { yes }=1)\end{array}$ & 0.46 & $\begin{array}{l}-0.05 \\
(0.31)\end{array}$ & -2.39 & $\begin{array}{l}-0.16 \\
(0.32)\end{array}$ & \\
\hline In Barcelona (city) (yes=1) & 0.49 & $\begin{array}{c}-0.44 \\
(0.4)\end{array}$ & & $\begin{array}{l}0.01 \\
(0.42)\end{array}$ & \\
\hline Civil governor (yes=1) & 0.18 & $\begin{array}{l}0.88^{* *} \\
(0.4)\end{array}$ & 43.57 & $\begin{array}{l}0.74 * \\
(0.42)\end{array}$ & 66.81 \\
\hline Mayor (yes=1) & 0.18 & $\begin{array}{l}1.25 * * \\
(0.44)\end{array}$ & 58.51 & $\begin{array}{c}0.43 \\
(0.42)\end{array}$ & \\
\hline Junta Local (yes=1) & 0.05 & 0.16 & & 0.25 & \\
\hline Type of strike issue (4) & & Yes & & Yes & \\
\hline Type of industry (11) & & Yes & & Yes & \\
\hline Year dummies (3) & & Yes & & Yes & \\
\hline Province dummies (3) & & Yes & & Yes & \\
\hline $\begin{array}{l}\text { Log L } \\
\text { Chi-Squared } \\
\% \text { correctly classified } * * * * \\
\text { Number of observations }\end{array}$ & & $\begin{array}{c}-181 \\
67.64 \\
71.97 \\
315\end{array}$ & & $\begin{array}{c}-172 \\
67.38 \\
69.43 \\
315\end{array}$ & \\
\hline
\end{tabular}

Source: Museu Social, years 1912-1915.

Notes: superscript ** indicates statistical significance at better than 5. Superscript * indicates significance at better than 10 per cent. Standard errors in parentheses. Marginal effects measure the percentage change on the estimated baseline probabilities caused by one standard deviation change in each particular variable's mean, holding all other variables at their sample means. The estimated marginal effects of the dummy variables are changes from 0 to 1. Marginal effects in italics are significant at standard levels of significance.

$* * * *$ correctly classified at cut-off probability $=0.5$.

Looking at the determinants of state intervention in Spanish strikes in 1905-1909 and the Catalan strikes in 1912-1915, it is clear that a strategic advantage existed in strikes attracting publicity. In the case of strikes in 1905-1909, state officials were more likely to intervene in large strikes, with an increase in one standard deviation in the number of stri- 
kers increasing the probability of the mediation by state officials by 35 per cent (table 3). Prefects were almost four times more likely to get involved in the case of strikes in cities over 50,000 inhabitants and where the provincial share of the anti-system vote (provincial share of vote for

TABLE 3

DETERMINANTS OF STATE INTERVENTION IN STRIKES, SPAIN 1905-1915

\begin{tabular}{|c|c|c|c|c|c|}
\hline \multirow[b]{2}{*}{ Variables } & \multirow[b]{2}{*}{ Means } & \multicolumn{2}{|c|}{$\begin{array}{c}\text { Stake intervention } \\
\text { in strikes, } 1905-9 \\
\text { Mean: } 0.17\end{array}$} & \multicolumn{2}{|c|}{$\begin{array}{c}\text { Intervention 1912-15. } \\
\text { Catalan strikes only } \\
\text { Mean: } 0.18\end{array}$} \\
\hline & & Coeff & Mg eff & Coeff & Mg eff \\
\hline Constant & 1 & $\begin{array}{c}-3.49 * * * \\
(0.93)\end{array}$ & & $\begin{array}{l}-7.64 * * * \\
(1.55)\end{array}$ & \\
\hline Log (days on strike) & $2.28 ; 2.19$ & $\begin{array}{l}-0.21^{* *} \\
(0.12)\end{array}$ & & $\begin{array}{c}0.17 \\
(1.15)\end{array}$ & \\
\hline Log (strikers) & $3.81 ; 4.14$ & $\begin{array}{l}0.23 * * \\
(0.11)\end{array}$ & 35.29 & $\begin{array}{c}0.62^{* * *} \\
(0.15)\end{array}$ & 151.67 \\
\hline $\begin{array}{l}\text { Log (strike partipation } \\
\text { rate) }\end{array}$ & $-0.45 ;-0.28$ & 0.31 & $(0.23)$ & -0.01 & $(0.35)$ \\
\hline $\begin{array}{l}\text { Share antisystem vote } \\
\text { in } 1907\end{array}$ & 0.11 & $\begin{array}{l}7.38 * * * \\
(2.42)\end{array}$ & 86.76 & & \\
\hline City 25,000-50,000 & 0.09 & $\begin{array}{c}0.67 \\
(0.59)\end{array}$ & & & \\
\hline City $50,000-100,000$ & 0.08 & $\begin{array}{l}1.08^{*} \\
(0.55)\end{array}$ & & & \\
\hline City over 100,000 & 0.4 & $\begin{array}{l}0.76^{*} \\
(0.39)\end{array}$ & 260 & & \\
\hline $\begin{array}{l}\text { Strike in Barcelona } \\
(\text { yes }=1)\end{array}$ & 0.49 & & & $\begin{array}{l}1.03 * * \\
(0.53)\end{array}$ & 159.5 \\
\hline Union workers (yes=1) & 0.81 & & & $\begin{array}{l}1.75^{* *} \\
(0.94)\end{array}$ & \\
\hline $\begin{array}{l}\text { Employers' association } \\
(\text { yes }=1)\end{array}$ & 0.46 & & & $\begin{array}{c}0.44 \\
(0.45)\end{array}$ & \\
\hline Type of strike issue (5) & & Yes & & Yes & \\
\hline Type of industry (11) & & Yes & & Yes & \\
\hline Year dummies (4) & & Yes & & Yes (3) & \\
\hline Region dummies (3) & & Yes & & Yes $^{\mathrm{a}}$ & \\
\hline $\log \mathrm{L}$ & & -191.52 & & -95.77 & \\
\hline Chi-Squared & & 122.39 & & 105.94 & \\
\hline$\%$ correctly classified $* * * *$ & & 85.77 & & 81.3 & \\
\hline Number of observations & & 548 & & 315 & \\
\hline
\end{tabular}

Notes: $* * *, * *, *$ indicate statistical significance at the better than 1,5 and 10 per cent in two-sided z-tests. Standard errors in parentheses. Marginal effects measure the percentage change on the estimated baseline probabilities caused by one standard deviation change in each particular variable's mean, holding all other variables at their sample means. The estimated marginal effects of the dummy variables are changes from 0 to 1 . Marginal effects in italics are significant at standard levels of significance. City size effects calculated with respect to strikes in cities with less than 10,000 inhabitants.

a 4 provincial dummies. $* * * *$ cut-off probability $=0.5$. 
socialists and republicans) was largest, with one increase in one standard deviation in the share increasing the probability of intervention by 87 per cent ${ }^{63}$. Considering Catalan strikes only (table 3 ), the prefect was more than twice as likely to intervene in Barcelona with respect to other cities and in larger than average strikes, with an increase in one standard deviation in the number of strikers triggering a 150 per cent increase in the probability of mediation, and three times more likely to intervene in strikes of union workers.

In large cities, a successful strike required that the authorities did not forbid meetings or crush demonstrations and picket lines to increase participation. However, especially in big cities, employers also badly needed the protection of their establishments from strikers and demanded that the authorities protect the freedom to work. Up until 1919, there is no evidence of employers organising effectively private polices and gangs of thugs to counterattack unions, except in isolated mining establishments and in some textile company towns ${ }^{64}$. In this sense, the monopoly over the violence directed against unions enjoyed by the state guaranteed that employers depended upon state officials to resist strikers. At least in the first two decades of the $20^{\text {th }}$ century and especially after 1910, employers' interests clashed with those of state officials wanting to protect public order and to avoid larger conflicts.

For example, in Catalonia, where prefects and employers were deeply divided on issues of public order, prefects were criticized for being governadors a la madrilenya (civil governors in the style of Madrid) because they did not handle conflicts firmly enough. In the parliamentary debate over the Barcelona general strike of 1902, Catalan deputies blamed the prefect of Barcelona, Miguel Socías, for having allowed a metal workers' strike to derive into a general strike. In this case, Socías was accused of tolerating the revolutionary meetings that preceded the general strike. A conservative journalist backing the complaints of employers remarked that «the responsibilities of the prefect do not entail meddling in the affairs between workers and employers, but only imposing the respect for the law and the liberty to work, the same for workers and employers, without siding with one or the other» ${ }^{65}$. The Catalan employer Rusiñol interrupted the speech of the Minister of Interior, who was defending his subordinate, and manifested that «we [employers] could not visit him, we did not trust him» ${ }^{66}$.

63 Provincial data on vote for republicans and socialists in the 1907 election in Martínez Cuadrado (1969), volume 2, data appendix.

64 Bengoechea (1994), 210.

65 Peris Mencheta, DSC 1902, 3919.

${ }_{66}$ DSC 1902, 3780. See another case, this time González Rothwoss in July 1903, in Romero-Maura (1985), 226-27. 
Likewise, in the mining strike of Bilbao of 1903, employers demanded the protection of their establishment from strikers and the enforcement of the freedom to work. Once the strike had started, a Basque deputy expressed in Parliament: «I require the Minister of Interior [...] to give firm instructions to the first civil authority in the province of Biscay so that everyone's rights are respected, especially the right to work for those who want to work» ${ }^{67}$. Later on, the main employers' association, the Círculo Mercantil é Industrial, wrote a telegram to some of its allied deputies demanding more protection from the state: «we beg you to ask the government about its position on the incidents that have taken place in Bilbao during the last strike which have forced us to close our establishments». And it was added: "we deplore the passivity of the authorities» ${ }^{68}$.

Similarly, in the large metal workers' strike of Barcelona in 1910, the prefect was accused by a conservative Catalan deputy: «it was a conflict limited to a negligible number of workers [...], but the civil governor of Barcelona tolerated every class of intimidation». And he went on to argue that «if the civil governor had remembered there existed a law on strikes, I am sure that we would not have reached today's situation [the general strike]. I don't doubt that had the prefect protected the freedom to work, nothing of this would have happened». According to him, when the strike was declared «the prefect said he was going to allow committees of strikers to go to the factories where the strike was not being supported to invite workers to join the strike». The deputy concluded bluntly: "the general strike has been fed by the prefect» ${ }^{69}$. The situation finally prompted employers to tell President Canalejas that:

«revolutionary meetings in which attacks to certain individuals are encouraged [...] go unpunished, with the result that those who decide to work are attacked on a daily basis. [...] We complain about this incitement to crime being tolerated, despite being penalized by our laws. The non-compliance of these laws is the main contributor to the current state of agitation and social anarchy» ${ }^{70}$.

However, in spite of the pressure brought to bear on them, state officials showed a great deal of autonomy. As Soledad Bengoechea put it in the case of the 1913 textile workers strike:

\footnotetext{
67 DSC 1903, 1285

68 Urquijo, DSC 1903, 1313; Fusi (1975), 241.

69 The Spanish sentence was "a los pechos del gobernador civil se ha ido amamantando esta huelga general». Bertran y Musitu, DSC 1910, 1630.

70 Ibid., 1630-1631. Groups expressing their opposition to state policy included Económica de Amigos del País, Fomento del Trabajo Nacional, Círculo de la Unión Mercantil, Cámara de Comercio and all the economic societies (sociedades económicas) of Barcelona.
} 
«From simple complaints, employers moved on to action. The visits to the prefect, Buenaventura Muñoz, multiplied. Employers demanded a firm handling of strikers and picket lines which did not allow the return to work for those wishing to do so. In spite of employers' pressure, Muñoz was not willing to use force but preferred to arbitrate the conflict through a negotiation with each of the parties» ${ }^{71}$.

It is not clear why state officials chose to favour conciliation over repression. In spite of the presence of some committed reformers like the civil governors of Conservative governments like Eduardo Sanz Escartín or Ángel Ossorio, who was close to Gabriel Maura Gamazo, another well known reformer ${ }^{72}$, the social doctrine of civil governors was never exposed clearly and probably was not homogenous. However, most of their actions show a more than occasional willingness to curb labour militancy by supporting some form of collective bargaining. Nonetheless, when strikes escalated in 1903 or 1910 and labour militancy did not give any proof of restraint, the same officials did not hesitate to crush the strike movement as they did in Barcelona in 1903, or with the general strike movement in 1901-1902 and 1910-1911.

The general strike of Sabadell in 1910 gives an example of the transition of state policy from conciliation to repression. Following an episode of lay offs of union workers in the French company Seydoux, the local federation of unions organized a strike in protest. The employers' association, the Unión Patronal, ordered a lock-out. The state initially adopted a conciliatory stance, while groups of civil guards protected some of the largest establishments to guarantee the freedom to work ${ }^{73}$. The conciliatory policy of the state reached the point that the Minister of Interior visited Sabadell in an attempt to seal an agreement between workers and employers. When the Minister called the contending parties to a meeting, the President of the employers' association did not attend it. Shortly after, the local federation of unions rallied workers towards the general strike. This brought about the prompt arrests of the leaders of the federation, the closing of unions offices, and the crushing of demonstrations.

Even in these episodes, government policy on arrests of strike leaders was not dramatically harsh, except under very exceptional circumstances such as the railway workers' strike of 1912, the general strike of 1917 or in the 1919 Barcelona general strike. Episodes like the Barcelona

\footnotetext{
71 Bengoechea (1994), 105.

72 Ossorio (1946), 45; in 1902 Ossorio published a book on workplace accidents: (Ossorio, 1902).

${ }^{73}$ Cuadrat (1976), 546-47.
} 
Tragic Week of 1909, which ended with a disproportionately hard response - several death penalties-, cannot be counted as a normal strike.

Looking at state policy in the most contentious city in the period, Barcelona, Soledad Bengoechea has argued that the policy of the government was the strategic arrest of the strike leaders to stop the strike early on ${ }^{74}$. Yet there is no sense that the state used all its coercive power to deter strikers. During the strike wave of the summer of 1903 when the state decided to switch to a more repressive policy, 371 persons were arrested out of 52,015 strikers (0.71 per cent). Of these 371, 274 ended up in prison. Of this last group, 181 spent less than one week in jail, while the longest stay in prison was three months. Of the 264 jailed workers, 127 were prosecuted but only one was finally convicted and there were 12 dismissals. On the remaining 115 cases, the Ministry of Interior García Álix issued a collective pardon through a Royal Decree passed on the $14^{\text {th }}$ August $1903^{75}$. In 1904, still in Barcelona, 160 strikers were arrested out of 11,047 (1.45 per cent). Of those, Miguel Sastre remarked «some of them went to prison, but they were freed almost immediately» ${ }^{76}$. In 1905, there were 1,676 strikers of whom 58 were arrested. Again, Sastre remarked that «most of the arrested strikers did not go to jail and were freed almost immediately by either the Prefect or the Judge» ${ }^{77}$. This situation did not change dramatically in the 1910s before 1919. For example, Ángel Pestaña of the National Confederation of Labour, commented on the situation from 1914 to 1919 that with respect to unions:

«Conservatives or Liberals were exactly the same. They went easily from tolerance to arbitrariness. In the blink of an eye, we were all in prison for no reason, then unexpectedly, all sorts of advantages were granted to us $[\ldots]$...

And he went on:

«the prisons in Barcelona could be suddenly filled with unionists, and then they would be freed immediately. For almost no reason, union locals were closed, union leaders were arrested, the payment of union dues was forbidden, and employers were granted the permission to lay off union workers. But in few days, all these severe measures were repealed ${ }^{78}$.

74 Bengoechea (2001), 341-355.

75 Sastre (1904), 72-74.

76 Sastre (1905), 85.

77 Sastre (1906), 67.

78 Pestaña (1974), 176. 
There were obvious and serious costs for labour activists in organizing collective action, but even when the state decided to repress labour leaders, the costs did not seem to be punitively high except in exceptional circumstances. When especially anarcho-syndicalist leaders were repressed in the early 1920s, it was the employers and the military, not the state, those who reacted strongly against labour militancy ${ }^{79}$.

\section{THE DYNAMICS OF WORKERS' AND EMPLOYERS' MOBILIZATION}

By occasionally supporting unions in big cities like Barcelona, Zaragoza, Valencia or Bilbao, the state gave some breathing space to parts of the labour movement connected with radical ideologies and anti-system political movements. By protecting strikers, state policies gave incentives to strategies aimed at enlarging participation in strikes through appeals to the general strike, public demonstrations, and violent picket lines. State policy, in this sense, reinforced the political outlook of unions by making them strategic bargainers with the state. By adopting a conciliatory stance in large cities, precisely where the links between the union movement and radical politics were closest, the state protected unions with close links to radical movements. The short-lived successes of the Regional Federation of Workers' Resistance Societies (FRSOR) in the early $20^{\text {th }}$ century, of Workers' Solidarity in 1907-9 in Barcelona or the National Confederation of Labour (CNT) in 1910-1911 and later on after 1916, and also to some extent the consistent advances made by the Socialist General Workers' Union (UGT) reflected, in fact, the strategic advantages of political, visible strikes in the largest cities and the ability of these unions to gather large numbers of workers forcing the state to intervene in the strike adopting a conciliatory stance. Unions, on the other hand, used the publicity of mass demonstrations in large cities to tilt public opinion in their favour. In this context, large working class institutions were in a far superior position to present strikers' demands as struggles for justice, rather than struggles to protect the interests of narrowly-defined groups of workers. Temma Kaplan in her account of the patterns of popular protest in Barcelona tells us how female textile workers and their children used to march in the main streets the Barcelona from the Plaza Cataluña to the building of the Civil Government during the general strike in the textile industry in $1913^{80}$. In the Bilbao minig strike of 1910, it was decided that the children of stri-

${ }^{79}$ Bengoechea (1998) is the standard reference.

${ }^{80}$ Kaplan (1992), 184. 
king miners would be lodged temporarily with families of workers in other trades. The images of parting children contributed decisively to the backing of the press and public opinion to the strike ${ }^{81}$.

Following the same logic, unions tended to group their demands in a rapid series of related strikes, an enlargement of conflicts which in some cases led to general strikes. This was, for instance, the case of the general strike in Barcelona in 1902, starting from the demands of metal workers, then extending them to other sectors, especially those involved with the distribution of goods (for example dockers) and with transport (like tramways) ${ }^{82}$. This was also the case of the mining strikes in the area of Bilbao, when miners extended the conflict to all other trades in Bilbao, especially transport ${ }^{83}$.

The ideological outlook of unions in the period did not reflect workers' ideological preferences but rather the survival probabilities of different types of unions. When confronted with state repression and the banning of «political» federations of unions like the FSROR in 1902 and the CNT in 1911, the remaining unions were those of above average bargaining power like the craft unions of local artisans and skilled workers, protected by their small numbers, control over the production process, and a strong sense of group identity. This contrasted with the experience of unions in large sectors like the metal industries, textiles or mining, employing a large mass of unskilled and semi-skilled workers, which went through periods of collective de-mobilization. The reduction of strike activity and the survival of bread-and-butter conservative unions that followed the crushing of strike waves did not mean that naturally conservative workers «hated» or disliked strikes and radical politics, as employers' supporters claimed and some labour historians seem to have accepted ${ }^{84}$, but instead reflected dwindling political opportunities for organized labour and the beginning of a cycle of state repression.

Evidence presented in this paper regarding state policy on strikes shows however that, even in periods of low strike activity like 1905-1909, the support provided by state officials to strikers was substantial. In periods of social upheaval, employers were well aware that strikes threatened established property rights. With employers' authority put to question, employers organized associations to check the rise of labour and lobby against the state's sometimes hesitant support for the labour movement. When organized, these employers' associations opposed any

\footnotetext{
81 Fusi (1975), 302.

82 Romero-Maura (1985), 211.

83 Fusi (1975), 238.

${ }^{84}$ For example, the foreword by Bartomeu Amengual in Sastre, 1903, 5-6. Amengual was Secretary of the Chamber of Commerce of Barcelona from 1902 to 1957. An example of a historian arguing workers are not interested in radical politics: Romero-Maura (1989), 240-242.
} 
mediation settlement with strikers and required the government simply to protect the freedom to work. In setting up these institutions, the employers' main objective was not to find a common voice in collective bargaining but to defend the open shop and, in extreme cases, to organize a lock-out. In general, they opposed any kind of state intervention in labour matters except the protection of their establishments from picket lines. For example, after the textile general strike in the Ter Valley in 1901, the Employers' Association of the Ter and Fresser Valleys, fearing «that the government, believing to curb the social problem [la cuestion social], with its lugubrious procession of strikes and mutinies, might sanction a law on permanent industrial tribunals», published a pamphlet to publicize «the principles backing our [their] deeply rooted views against the passing by the state of arbitration and conciliation tribunals» ${ }^{85}$. Several examples show that employers mainly mobilized to check working class mobilization and also to lobby state officials to protect the freedom to work during strikes.

In Biscay, the Círculo Minero, the employers' association of Biscay mining employers, was not concerned with labour issues at its inception. Created in 1887, the Círculo was on the verge of disappearing having failed to attract enough members. In 1887, the association lobbied against the tax imposed by the municipality of Bilbao on each ton of exported iron ${ }^{86}$. But with little activity in the following two years, the Círculo only met once. However, the May Day general strike of 1890 radically altered the Circulo's focus. In 1891, it agreed to finance the building of barracks to shelter units of the Guardia Civil in the mining towns. Other means of countering the spread of unions and the Socialist Party included the call to crush strikes and union meetings, the laying off of Socialist workers and the drawing up of «black lists» to force militant workers to migrate ${ }^{87}$. In the mid 1890s, a federation of employers' associations, the Centro Industrial de Vizcaya, united diverse employers' associations into one powerful employers' union ${ }^{88}$.

Likewise, the Barcelona building construction employers' association, the Centro de Contratistas de Obras y de Maestros Albañiles, was originally created in 1892 mainly to lobby local and state authorities and after 1900 played an important role in the protests against the fiscal reforms undertaken by the Conservative Finance Minister Raimundo Fernández Villaverde ${ }^{89}$. However, after a strike in 1901, most of the

\footnotetext{
${ }^{85}$ Asociación de Fabricantes de las Cuencas del Ter y del Fresser (1902); Rusiñol (1902).

86 Díaz Morlan (1999), 48.

87 Torres Villanueva (1998), 72-74

88 Olábarri (1978), 224-247.

89 Bengoechea (1994), 60.
} 
emphasis of the Centro was directed towards the co-ordination of employers' resistance to strikes. Similarly, the Sociedad de Industriales Mecánicos and the Gremio de Industriales Metalarios, uniting employers of the metal industries of Barcelona, were organized around 1900 in response to the tax reforms of Villaverde ${ }^{90}$. As in the case of building construction, a new Sociedad de Industriales Mecánicos y Metalarios was created in 1903 to curb labour unrest ${ }^{91}$. In the strike wave of 1910 , these two sectors formed the backbone of the newly constituted Federacion Patronal, an attempt to unite all employers of Barcelona into one single organisation ${ }^{92}$.

\section{CONCLUSIONS}

This paper tries to understand the failure to implement institutional change in Spanish industrial relations and to describe an existing institutional equilibrium by analyzing state policy on the contested issue of the right to associate and strike in early $20^{\text {th }}$ century Spain. I argue that the effective formalization of a system of industrial relations failed especially because the state did not force employers to participate in formal collective bargaining institutions. Despite the failure to enforce legislation, I show how there was already an informal system of strike arbitration aimed at protecting public order in the main Spanish cities and a strategy by the state to control working class mobilization by recognizing limited rights to unions and strikers. I stress that the state generally sided with the interests of workers forcing employers to recognize some of the demands of workers to end the strike quickly. This institutional capacity of the state depended on its monopoly of violence and its ability to guarantee the freedom to work. During the Restauración, employers and state officials had frequent conflicts over the protection of the freedom to work. Finally, the paper evaluates the possible dynamic effects of state intervention in strikes. I argue that state intervention protected radical, politicised unions in the main cities and alienated employers against the Restoration state.

This article might provide a basis for an understanding of the processes of collective mobilisation and de-mobilisation in Spain. However, the main aim here is neither to provide a definitive analysis of the dynamics of union growth in Spain during the Restauración, nor to offer an

90 Ibid., 78-79.

91 Ibid., 83.

92 Ibid., 110. Other cases of employers' mobilization, for example after the general strike in Logroño in 1904 and 1908: Gil Andrés (2000), 86-92. 
explanation for the peculiar institutional characteristics of Spanish unions and other forms of working class collective action (which would require more comparative analysis). I want to stress, however, the importance of putting the state at the centre of any account of the Spanish labour movement. Historians have emphasised bottom-up forces when explaining the rising trend in working class collective action in Spain. One of the conclusions reached here is the need to balance the story between bottom-up and top-down forces, focusing on the crucial interaction between strikers, employers, and state officials.

\section{REFERENCES}

Diario de Sesiones del Congreso de los Diputados (DSC).

Reglamento del Centro de Contrastistas de Obras y Maestros Albañiles de Barcelona (1900), Barcelona.

Asociación de Fabricantes de las Cuencas del Ter y del Fresser (1902): Los jurados mixtos en España, Barcelona: Henrich y Cía.

AzcÁrate, G. de (1904): Estudio sobre los deberes de la riqueza (speech delivered in November 1892), Barcelona.

Buylla, A., and GonZÁlez Alegre, A. (1910): La protección del obrero (acción social y acción política), Madrid: Librería General de Victoriano Suárez.

Buylla, A.; Posada, A., and Morote, L. (1986 [1902]): El Instituto de Trabajo. Datos para la historia del reformismo social en España, Madrid: Ministerio de Trabajo y Seguridad Social.

FERNÁNDEZ JimÉnEZ, M. (1904): El problema obrero y los partidos españoles, Granada: Paulino Ventura.

Financiero Hispano-Americano (1916): El problema ferroviario. Proceso social y jurídico de nuestro derecho a huelgas. Recopilación de documentos de actualidad y comentarios, Madrid.

GASCÓN Y MARÍN, J. (1907): Los sindicatos y la libertad de contratación, Barcelona: Henrich y Cía.

INSTITUTO DE REFORMAS SOCIALES (IRS) (1907): Estadística de asociación obrera en 1 de noviembre de 1904, Madrid: Imprenta de los Sucesores de M. Minuesa de los Ríos.

- (1905-1922): Estadística de huelgas, Madrid: Imprenta de los Sucesores de M. Minuesa de los Ríos.

- (1908-1922): Memoria general de la inspección de trabajo, Madrid: Imprenta de los Sucesores de M. Minuesa de los Ríos.

Maura Gamazo, G. (1901): Los jurados mixtos para dirimir las diferencias entre patronos y obreros y para prevenir ó remediar las huelgas, Madrid: Imprenta del Asilo de Huérfanos de S. C. de Jesús.

Museu Social (1913-16): Anuari d'estadística social de Catalunya, Barcelona.

Ossorio, A. (1902): Accidentes de trabajo, Madrid: Imprenta de Ricardo Rojas.

Pestaña, A. (1974): Trayectoria sindicalista, Madrid: Tebas.

Rusiñol, A. (1902): Bases para la creación y funcionamiento de los jurados mixtos en Manlleu, Barcelona: Tip. Domingo Casanovas. 
Sanz Escartín, E. (1896): El individuo y la reforma social, Madrid: Tip., Fund. y fábrica de tintas de los hijos de J. A. García.

SASTRE SANNA, M. (1904): Las huelgas de Barcelona y sus resultados durante el año 1903, Barcelona: Tip. Ramon Pujol.

- (1905): Las huelgas de Barcelona y sus resultados durante el año 1904, Barcelona: Tip. La Industria de Manuel Tasis.

- (1906): Las huelgas de Barcelona y sus resultados durante el año 1905, Barcelona: Tip. La Hormiga de Oro.

- (1907): Las huelgas de Barcelona y sus resultados durante el año 1906, Barcelona: Tip. La Hormiga de Oro.

- (1908): Las huelgas de Barcelona y sus resultados durante el año 1907, Barcelona: Tip. Valls y Borrás.

- (1909): Las huelgas de Barcelona y sus resultados durante el año 1908, Barcelona: Tip. Valls y Borrás.

- (1911): Las huelgas de Barcelona y sus resultados durante el año 1909, Barcelona: Acción Social Popular.

- (1915): Las huelgas en Barcelona durante los años 1910 al 1914 ambos inclusive, Barcelona: Editorial Barcelonesa.

ZANCADA, P. (1902): El obrero español. Notas para una historia política, Barcelona: Editorial Maucci.

\section{BIBLIOGRAPHY}

Álvarez Junco, J. (1990): El emperador del Paralelo: Lerroux y la demagogia populista, Madrid: Alianza editorial.

BengoecheA, S. (1994): Organització patronal i conflictivitat social a Catalunya, Barcelona: Publicacions de l'Abadia de Montserrat.

Bengoechea, S. (1998): El locaut de Barcelona (1919-20), Barcelona: Curial.

- (2001): «Conflictividad social en Barcelona durante 1903 (un estudio realizado en base a la correspondencia cruzada entre el ministro de la Gobernación, Antonio Maura, con los gobernadores civiles de Barcelona y ciertos sectores de la patronal)», in C. Arenas Posadas, F. Puntas and J. Pons (eds.), Trabajo y relaciones laborales en la España contemporánea, Sevilla: Mergablum, pp. 341-355.

Brenan, G. (1943): The Spanish labyrinth. An account of the social and political background of the Civil War, Cambridge: Cambridge University Press.

BYRne, J. (1992): "Trabajo y conflictividad en el sector de la construcción en Madrid, 1900-1914». Sociología del Trabajo, 15 (Spring), pp. 115-142.

CARD, D., and Olson, C. A. (1995): «Bargaining power, strike durations, and wage outcomes: an analysis of strikes in the 1880s». Journal of Labor Economics 13 (1), pp. 32-61.

CuAdRAT, X. (1976): Socialismo y anarquismo en Cataluña. Los orígenes de la CNT, Madrid: Revista de Trabajo.

Culla, J. B. (1986): El republicanisme lerrouxista a Catalunya (1901-1923), Barcelona: Curial.

De la Cierva, J. (1955): Notas de mi vida, Madrid: Instituto Editorial Reus.

Díaz del Moral, J. (1973): Historia de las agitaciones campesinas andaluzas: Córdoba. Antecedentes de una reforma agraria, Madrid: Alianza editorial. 
Díaz MoRlan, P. (1999): Horacio Echevarrieta, 1870-1963. El capitalista republicano, Madrid: LID.

FERRER, J. (1974): El primer «Primer de Maig» a Catalunya, Barcelona: La Llar del Llibre.

FreEman, R. (1997): “"Spurts” in Union Growth: Defining Moments and Social Processes». NBER working paper number 6012.

FRIEDMAN, G. (1988): «Strike success and union ideology: the US and France, 18801914». Journal of Economic History 48 (1), pp. 1-25.

- (1998): State-Making and Labor Movements. France and the United States, 18761914, Ithaca, NY: Cornell University Press.

FusI, J. P. (1975): Política obrera en el País Vasco, 1880-1923, Madrid: Turner.

GABriel, P. (1981): Classe Obrera i Sindicats a Catalunya, 1903-1920, Unpublished $\mathrm{PhD}$ dissertation, Universitat de Barcelona.

GIL ANDRÉs, C. (2000): Echarse a la calle. Amotinados, huelguistas y revolucionarios (La Rioja, 1890-1936), Zaragoza: Prensas Universitarias.

Huberman, M., and Young, D. (1999): "Cross-border unions: Internationals in Canada, 1901-1914». Explorations in Economic History, 36, pp. 204-231.

Huberman, M., and Young, D. (2002): "Hope against hope: strike activity in Canada, 1920-1939». Explorations in Economic History, 39, pp. 315-354.

IZARD, M. (1973): Industrialización y obrerismo: las Tres Clases de Vapor, 1869-1913, Barcelona: Ariel.

Kaplan, T. (1992): Red city, blue period. Social movements in Picasso's Barcelona, Berkeley, CA: University of California Press.

KNIGHT, J. (1992): Institutions and Social Conflict, Cambridge, UK: Cambridge University Press.

LiBECAP, G. D. (1989): «Distributional Issues in Contracting for Property Rights». Journal of International and Theoretical Economics, 145, pp. 6-31.

Mailath, G. J., and Postlewhite, A. (1990): «Asymmetric Information Bargaining Problems with Many Agents». Review of Economic Studies, 57 (July), pp. 351-67.

Malefakis, E. (1993): «A comparative analysis of workers' movements in Spain and Italy», in R. Gunther (ed.), Politics, society, and democracy: the case of Spain, Boulder, Colorado: Westview.

Martin, B. (1990): The Agony of Modernization. Labor and Industrialization in Spain, Ithaca, NY: Cornell University Press.

Martínez Cuadrado, M. (1969): Elecciones y partidos políticos, 1868-1936, Madrid: Taurus.

Meaker, G. H. (1974): The Revolutionary Left in Spain, 1914-1923, Palo Alto: Stanford University Press.

NorTH, D. C. (1987): «Institutions, Transaction Costs, and Economic Growth». Economic Inquiry, 25 (July), pp. 419-428.

OlÁBARRI, I. (1978): Relaciones laborales en Vizcaya (1890-1936), Durango: Leopoldo Zugaza, (ed).

Olson, M. (1995, 16 $6^{\text {th }}$ printing): The Logic of Collective Action: Public Goods and the Theory of Groups, Cambridge, MA: Harvard University Press.

Ossorio, A. (1946): Mis memorias, Buenos Aires: Losada.

REIG, R. (1986): Blasquistas y clericales: la lucha por la ciudad de Valencia de 1900, Valencia: Alfons el Magnànim.

RichARDS, A. (2002): «Mobilizing the powerless: collective protest action of the unemployed in the internar period». Working paper, 2002/175: Fundación Juan March. 
Risoues Corbella, M. (1995): El govern civil de Barcelona al segle XIX, Barcelona: Publicacions de l'Abadia de Montserrat.

Romero-Maura, J. (1989): La "Rosa de Fuego»: el obrerismo barcelonés de 1899 a 1909, Madrid: Alianza editorial.

ShorTer, E., and Tilly, C. (1974): Strikes in France, 1830-1968, Cambridge, UK: Cambridge University Press.

SHUBERT, A. (1984): Hacia la Revolución: orígenes sociales del movimiento obrero en Asturias (1860-1934), Barcelona: Crítica.

Sмiтн, A. (1991): «Trabajadores "dignos" en profesiones "honradas": los oficios y la formación de la clase obrera barcelonesa (1899-1914)». Hispania, LVI/2, pp. 331-376.

TorRes Villanueva, E. (1998): Ramón de la Sota, 1857-1936. Un empresario vasco, Madrid: LID.

Ulman, J. C. (1968): The Tragic Week. A Study of Anticlericalism in Spain, 1875-1912, Cambridge, MA: Harvard University Press. 
